\title{
CATALASE ACTIVITY AS SIGNAL OF ANTIOXYDANT SYSTEM AFFECTION UNDER INFLUENCE OF LIMB ISCHEMIA-REPERFUSION
}

\author{
Nataliya Volotovska \\ Department of Physiology, Bioethics and Biosafety \\ I. Horbachevskyi Ternopil National Medical University \\ 1 Voli ave., Ternopil, Ukraine, 46001 \\ volotovskanv@tdmu.edu.ua
}

\begin{abstract}
The use of hemostatic tourniquet is a proved means of primary care. However, systemic disorders, as well as ultrastructural, in the area of compression can significantly worsen the condition of the injured organism.

The aim. Estimation of catalase level in rats' liver on the background of modifications of ischemic-reperfusion syndrome to know the severest pathogenic combination for organism.

Materials and methods. 260 white adult male rats were divided into 5 groups: control (KG), EG1 - simulation of isolated ischemia-reperfusion syndrome (IRS) of the limb, EG2 - simulation of isolated volumetric blood loss, EG3 - combination of IRS of the limb with blood loss, EG4 - simulation of isolated mechanical injury of the thigh, EG5 - combination of IRS of the limb and mechanical injury. The variability of catalase level in liver was analyzed.

Results. It was found that each of the experimental interventions has led to changes of catalase activity in the liver. The most expressed pathological expressions were observed on the $3^{\text {rd }}$ after interventions, when the studied index in EG3 was lower than in EG1 and EG2 in 6.2 times and by $33.1 \%$. On the $7^{\text {th }}$ day catalase activity in EG3 was in 9.4 times and by $44.5 \%$ times lower than in EG1 and in EG2 data concordantly. The combination of limb ischemia-reperfusion with blood loss in EG3 led to exhausting of liver antioxydant enzyme catalase in the most critical posttraumatic period (day 3). The same, but less significant effect was registered in the group of combination of mechanical trauma with ischemia-reperfusion in EG5. This proved the role of the tourniquet as a factor that complicated the course of traumatic disease due to ischemic reperfusion.

Conclusions. In this experiment, founded risk factors of combination of ischemia-reperfusion with heavy blood loss emphasized the importance and particular attention on such widespread method of bleeding tratment, as the imposition of a tourniquet, as in our experiment it triggered risk factors of ischemia-reperfusion. It was shown katalase activity depression respectively to the periods of increasing of lipid peroxydation. There was peculiarity, that on the base of isolated IRS catalase activity was increased in 2.5 times comparely to control group, whereas the hardest depression of it was found on the background of IRS, combined with blood loss - catalase activity was lower, comparely to KG - in 2.5 times. The importance of understanding the suppression of hepatocytes' antyoxydants is great, as it might help in prevention the development of liver failure or hepatorenal syndrome on the background of limb ischemia-reperfusion.
\end{abstract}

Keywords: ischemia-reperfusion, blood loss, trauma, tourniquet, catalase, experiment, liver, lipid peroxidation.

DOI: $10.21303 / 2504-5679.2021 .001648$

\section{Introduction}

Although it is known that oxidative stress is the predominant cause of aging [1], but blood loss of various origin can trigger it as well and activate lipid peroxidation $[2,3]$. One of the first enzymes to fight against reactive oxygen is catalase [4]. According to the newest data, catalase recognized as a key factor that can inhibit the growth of $\mathrm{H}_{2} \mathrm{O}_{2}$, especially when long term course of pathological process is observed [5].

It is known that the optimal $\mathrm{pH}$ for efficient catalase activity is $6-8$ [6], and various pathological conditions, including massive blood loss or sceletal injury, triger increasing of acidity due to increased concentration of hydrogen ions. It is resulted with development of metabolic acidosis and also reducing of reserve alkalinity. Such conditions significantly block catalase power, enzyme will not be able to protect cells membranes at such a shift in $\mathrm{pH}$. It must be mentioned, that one of the serious factors that triggers a heavy release of free radicals into the systemic circulation is ischemia-reperfusion [7].

Peroxidation is activated due to hypoxia in the tightened area, and its derivatives has been accumulated as a result of compression and cessation of blood supply locally. After repairing the 
blood circulation in affected limb these dangerous biologically active substances are released to the blood. Rhabdomyolysis products also reach the systemic bloodstream [8]. Also among the initial factors that trigger systemic ischemic-reperfusion injury is an immediate nonspecific inflammatory response [9].

Thus, the newest literary sources promulgate that the use of hemostatic tourniquet, including its application on the battlefield, by activating pathological chains leads to intensification of excretory function of the kidneys and overwork of the liver with next exhausting of its detoxification functions $[10,11]$. In available literature there is not enough information about the systemic manifestations of limb ischemia-reperfusion. Therefore, that fact shows necessity of studying of future methods of prevention of IRS complications.

The aim of the work - to estimate catalase level in rats with modifications of ischemicreperfusion syndrome to know the severest pathogenic combination for organism.

\section{Materials and methods}

Experiments were performed in the vivarium of I. Ya. Gorbachevsky Ternopil National Medical University of the Ministry of Health of Ukraine in the morning. Special room had stable temperature $\left(18-22^{\circ} \mathrm{C}\right)$, relative humidity $(40-60 \%)$ and illumination 250 lux in the period of summer and autumn of 2016. 260 nonlinear male rats (200-250 g) were used in experiments and all animals were divided into 5 groups: control and 5 experimental (10 animals each). In EG1 animal were simulated with ischemia-reperfusion of the limb. Under thiopental-sodium anesthesia $\left(40 \mathrm{mg} \cdot \mathrm{kg}^{-1}\right.$ body weight intraperitoneal), SWAT-T (US) tourniquet with width $10 \mathrm{~mm}$ was applied to the thigh of an animal and adequately corresponds pressure of the tourniquet when applied to the thigh of an adult human. According to the literature, such a tourniquet is characterized by minimal negative traumatic effects on the underlying tissues due to its width and long-term pain threshold [12]. The tourniquet was tightened according to the applied effective pressure marking, which is able to stop the blood flow. In EG2 under conditions of anesthesia, acute heavy blood loss (up to $40 \%$ of volume of circulating blood) was modelled by puncture of the femoral vein with further hemostasis. In EG3, these two injuries were combined. In EG4 animals were done with mechanical trauma of the femur with aim of closed fracture simulation. The combination of ischemia-reperfusion of the thigh with mechanical trauma was modelled in EG5. Animals were eliminated from experiment at the 1st hour after intervention, and on the 1st, 3rd, 7-th and 14-th days after trauma on the base of thiopental-sodium anaesthesia by total bleeding from the heart. In the case of KG animals, they were anesthetized with an equivalent dose of sodium thiopental and material were collected for the study, as from the experimental groups.

The study design was considered with the rules of the «European Convention for the Protection of Vertebrate Animals Used for Experimental and Other Scientific Purposes» (European Convention, 1984) and Law of the Ministry of Health of Ukraine No. 690 [13], considered by the commission at a meeting of the commission on bioethics of I. Ya. Gorbachevsky Ternopil National Medical University of the Ministry of Health of Ukraine No. 61 by 11.01.2021.

In the homogenate of the liver [14] an activity of the key component of the enzymatic link of antioxidant protection and antioxidant mechanisms - catalase -was established.

A statistical analysis on obtained data was performed by Excel (Microsoft, USA). In addition to the absolute values, which are presented in the tables in the form of median (Me), lower and upper quartiles (LQ; UQ), the deviation of each indicator as a percentage to the control level $(100.0 \%)$ was calculated. To rate the probability of differences we defined the peculiarities of the variational grouping of indicators in the compared groups. Due to the lack of a normal grouping, the nonparametric Mann-Whitney test was used. The differences were considered as a true when the probability of the null hypothesis was not more than $5 \%(p<0.05)$.

\section{Results}

As could be seen from the data of Table 1 on the background of ischemia-reperfusion, combined with various additional injuries modelling, affection of the catalase activity was ambiguously, but in accordance to the severity of the intervention. Thus, after 1 hour in EG1 (on the 
background of isolated ischemia-reperfusion) the indicator exceeded the data of the control group $(\mathrm{KG})$ by $12.6 \%\left(0.56 \mu \mathrm{cat} \cdot \mathrm{kg}^{-1}\right)[4.41-4.97=0.56]$, after which a rapid increase in the concentration of the enzyme in the liver tissue was noticed. On the 1st day after the intervention, it was higher than in the KG data by $17.9 \%\left(0.79 \mu \mathrm{cat} \cdot \mathrm{kg}^{-1}\right)$, and on the $3^{\text {rd }}$ and $7^{\text {th }}$ days exceeded the KG by 2.5 times $\left(6.51 \mu \mathrm{cat} \cdot \mathrm{kg}^{-1}\right)$ and 2.8 times $\left(7.95 \mu \mathrm{cat} \cdot \mathrm{kg}^{-1}\right)$, concordantly.

Table 1

Liver catalase activity $\left(\mu \mathrm{cat} \cdot \mathrm{kg}^{-1}\right)$ after ischemia reperfusion of the limb and blood loss (Me (LQ; UQ)) median (lower and upper quartiles)

\begin{tabular}{|c|c|c|c|c|c|}
\hline \multirow{2}{*}{ Experimental group } & \multicolumn{5}{|c|}{ Reperfusion period } \\
\hline & $1^{\text {st }}$ hour & $1^{\text {st }}$ day & $3^{\text {rd day }}$ & $7^{\text {th }}$ day & $14^{\text {th }}$ day \\
\hline \multicolumn{6}{|c|}{$K G$ Control $=4.41(4.16 ; 4.74)(n=10)$} \\
\hline $\begin{array}{l}E G 1 \\
\text { isolated ischemia } \\
\text { reperfusion }(n=10)\end{array}$ & $4.97(4.60 ; 5.30)$ & $5.20^{*}(4.94 ; 5.40)$ & $10.92^{*}(10.44 ; 11.16)$ & $12.36^{*}(11.59 ; 12.91)$ & $8.38^{*}(8.17 ; 8.90)$ \\
\hline $\begin{array}{c}E G 2 \\
\text { Blood loss }(n=7)\end{array}$ & $3.00^{*}(2.97 ; 3.22)$ & $2.27^{*}(2.21 ; 2.72)$ & $2.63^{*}(2.52 ; 2.75)$ & $2.38^{*}(2.20 ; 2.45)$ & $2.47^{*}(2.42 ; 2.50)$ \\
\hline $\begin{array}{c}E G 3 \\
\text { ischemia-reperfusion }+ \\
\text { Blood loss }(n=6)\end{array}$ & $2.83^{*}(2.70 ; 2.95)$ & $2.16^{*}(1.97 ; 2.32)$ & $1.76^{*}(1.68 ; 1.85)$ & $1.32^{*}(1.24 ; 1.44)$ & $1.62^{*}(1.60 ; 1.75)$ \\
\hline$p_{1-3}$ & $<0.05$ & $<0.05$ & $<0.05$ & $<0.05$ & $<0.05$ \\
\hline$p_{2-3}$ & $>0.05$ & $>0.05$ & $<0.05$ & $<0.05$ & $<0.05$ \\
\hline
\end{tabular}

Note: ${ }^{*}$ - differences in relation to the control group are statistically significant $(p<0.05) ; p_{1-3}-$ the probability of differences in relation to experimental groups 1 i 3; $p_{2-3}$ - the probability of differences in relation to experimental groups $2 i 3$

On the $14^{\text {th }}$ day, the indicator remained significantly higher than in the $\mathrm{KG}-$ by $90.2 \%$ $\left(3.97 \mu \mathrm{cat} \cdot \mathrm{kg}^{-1}\right)$.

On the background of isolated volumetric blood loss after 1 hour in the EG2 the activity decreased by $32 \%\left(1.41 \mu \mathrm{cat} \cdot \mathrm{kg}^{-1}\right)$, compared with KG. In subsequent periods, as a result of hemic hypoxia, the activity of the indicator remained suppressed - on the $1^{\text {st }}, 3^{\text {rd }}$, $7^{\text {th }}$ days it was lower by $49.2 \%\left(2.14 \mu \mathrm{cat} \cdot \mathrm{kg}^{-1}\right)$, by $40.4 \%\left(1.78 \mu \mathrm{cat} \cdot \mathrm{kg}^{-1}\right)$ and by $46 \%\left(2.03 \mu \mathrm{cat} \cdot \mathrm{kg}^{-1}\right)$, concordantly. On the $14^{\text {th }}$ day statistically significance was $44 \%\left(1.94 \mu\right.$ cat $\left.\mathrm{kg}^{-1}\right)$ lower than in KG.

On the background of IR combined with blood loss in the EG3, after the $1^{\text {st }}$ hour after the intervention, catalase activity decreased by $36.9 \%\left(1.58 \mu \mathrm{cat} \cdot \mathrm{kg}^{-1}\right)$ compared with $\mathrm{KG}$. And on $1^{\text {st }}$, $3^{\text {rd }}, 7^{\text {th }}$ and $14^{\text {th }}$ days the indicator was lower in comparison with $\mathrm{KG}$ in 2.1 times $\left(2.25 \mu \mathrm{cat} \cdot \mathrm{kg}^{-1}\right)$, in 2.5 times $\left(2.65 \mu\right.$ cat $\left.\mathrm{kg}^{-1}\right)$, in 3.3 times $\left(3.09 \mu \mathrm{cat} \cdot \mathrm{kg}^{-1}\right)$, in 2.7 times $\left(2.79 \mu \mathrm{cat} \cdot \mathrm{kg}^{-1}\right)$, respectively.

As could be seen from Table 2, on the background of an isolated injury in EG4 after $1^{\text {st }}$ hour, the rate decreased slightly - by $7.9 \%\left(0.35 \mu\right.$ cat $\left.\cdot \mathrm{kg}^{-1}\right)$ compared with KG. On the $1^{\text {st }}$, $3^{\text {rd }}, 7^{\text {th }}$ and $14^{\text {th }}$ days it was lower than in KG by $14.7 \%\left(0.65 \mu \mathrm{cat} \cdot \mathrm{kg}^{-1}\right), 16.8 \%\left(0.74 \mu \mathrm{cat}^{\circ} \mathrm{kg}^{-1}\right)$, $17.5 \%\left(0.77 \mu \mathrm{cat} \cdot \mathrm{kg}^{-1}\right)$ and $8.4 \%\left(0.37 \mu \mathrm{cat} \cdot \mathrm{kg}^{-1}\right)$, respectively.

Decrease in catalase activity on the background of mechanical trauma combined with IR in EG5 was slightly more expressed, compared with EG4. After the $1^{\text {st }}$ hour the indicator was lower than in the KG level by $12.9 \%\left(0.57 \mu \mathrm{cat} \cdot \mathrm{kg}^{-1}\right)$. On the $1^{\text {st }}, 3^{\text {rd }}, 7^{\text {th }}$ and $14^{\text {th }}$ days, it remained reduced, compared with KG by $27.3 \%\left(1.22 \mu\right.$ cat $\left.\cdot \mathrm{kg}^{-1}\right), 35.4 \%\left(1.56 \mu \mathrm{cat} \cdot \mathrm{kg}^{-1}\right)$, by $46.2 \%\left(2.04 \mu \mathrm{cat} \cdot \mathrm{kg}^{-1}\right)$ and $39.9 \%\left(1.76 \mu \mathrm{cat} \cdot \mathrm{kg}^{-1}\right)$, respectively.

The dynamics of the catalase activity on the background of each intervention had its own characteristics, but in general it was found that isolated IR led to an adequate increase in catalase activity, while other types of intervention were excessive for its possible compensatory properties. Thus, it was found that in the EG1 the indicator exceeded the data of the $1^{\text {st }}$ hour by $4.6 \%\left(0.23 \mu \mathrm{cat} \cdot \mathrm{kg}^{-1}\right)[5.20-4.97=0.23]$, after that the activity increased and on the 
$3^{\text {rd }}$ day was higher than the data of the $1^{\text {st }}$ hour and $1^{\text {st }}$ day by 2.2 times $\left(5.95 \mu\right.$ cat $\left.\mathrm{kg}^{-1}\right)$ and by 2.1 times $\left(5.75 \mu \mathrm{cat} \cdot \mathrm{kg}^{-1}\right)$, respectively. On the $7^{\text {th }}$ day, the indicator increased slightly, compared with the $3^{\text {rd }}$ day by $13.2 \%\left(1.44 \mu \mathrm{cat} \cdot \mathrm{kg}^{-1}\right)$, but remained significantly increased, compared with the $1^{\text {st }}$ hour in 2.5 times $\left(7.39 \mu\right.$ cat $\left.\mathrm{kg}^{-1}\right)$, compared to the $1^{\text {st }}$ day it was increased in 2.4 times $\left(7.16 \mu \mathrm{cat} \cdot \mathrm{kg}^{-1}\right)$. On the $14^{\text {th }}$ day, despite a certain decrease in activity compared to the $3^{\text {rd }}$ and $7^{\text {th }}$ days by $23.3 \%\left(2.54 \mu \mathrm{cat} \cdot \mathrm{kg}^{-1}\right)$ and $32.2 \%\left(3.98 \mu \mathrm{cat} \cdot \mathrm{kg}^{-1}\right)$, respectively, it unfortunately remained increased compared to the $1^{\text {st }}$ hour by $68.6 \%\left(3.41 \mu \mathrm{cat} \cdot \mathrm{kg}^{-1}\right)$ and compared to the data of the $1^{\text {st }}$ day by $61.2 \%\left(3.18 \mu \mathrm{cat} \cdot \mathrm{kg}^{-1}\right)$, respectively. Such changes in catalase activity can probably be explained by the depletion of the compensatory capacity of this enzyme, because for so long the liver was able to maintain its protective function. Similar dynamics is established in [15]. The activity of catalase in muscle tissue was also studied: it was found that it gradually increased to $7^{\text {th }}$ day, after which it sharply decreased by $14^{\text {th }}$ days. Such dynamics is evaluated as the absence of decompensated antioxidant system violation.

Table 2

Liver catalase activity $\left(\mu \mathrm{cat} \cdot \mathrm{kg}^{-1}\right.$ ) after ischemia reperfusion of the limb and skeletal trauma (Me (LQ; UQ)) median (lower and upper quartiles)

\begin{tabular}{|c|c|c|c|c|c|}
\hline \multirow{2}{*}{ Experimental group } & \multicolumn{5}{|c|}{ Reperfusion period } \\
\hline & $1^{\text {st }}$ hour & $1^{\text {st }}$ hour & $1^{\text {st }}$ hour & $1^{\text {st }}$ hour & $1^{\text {st }}$ hour \\
\hline \multicolumn{6}{|c|}{$K G$ Control $=4.41(4.16 ; 4.74)(n=10)$} \\
\hline $\begin{array}{c}E G 4 \\
\text { Trauma }(n=10)\end{array}$ & $4.06(3.57 ; 4.23)$ & $3.76(3.63 ; 4.17)$ & $3.67^{*}(3.56 ; 3.77)$ & $3.64^{*}(3.51 ; 3.78)$ & $4.04(3.81 ; 4.18)$ \\
\hline $\begin{array}{c}E G 5 \\
\text { ischemia-reperfusion }+ \\
\text { trauma }(n=9)\end{array}$ & $3.84(3.58 ; 4.04)$ & $3.19^{*}(3.10 ; 3.35)$ & $2.85^{*}(2.77 ; 3.13)$ & $2.37^{*}(2.10 ; 2.40)$ & $2.65(2.50 ; 2.82)$ \\
\hline$p_{1-5}$ & $<0.05$ & $<0.05$ & $<0.05$ & $<0.05$ & $<0.05$ \\
\hline$p_{4-5}$ & $>0.05$ & $<0.05$ & $<0.05$ & $<0.05$ & $<0.05$ \\
\hline
\end{tabular}

Note: $p_{1-5}$ - the probability of differences in relation to experimental groups 1 and $5(p<0.05) ; p_{4-5}$ - the probability of differences with respect to experimental groups 4 and 5

In the EG2, the indicator remained stable at a quite low level: on the $1^{\text {st }}$ day it was lower than the data of the $1^{\text {st }}$ hour by $24.3 \%\left(0.73 \mu \mathrm{cat} \cdot \mathrm{kg}^{-1}\right)$, and the indicator of the $3^{\text {rd }}$ day, although it was lower than the data of the $1^{\text {st }}$ hour by $12.3 \%\left(0.37 \mu \mathrm{cat} \cdot \mathrm{kg}^{-1}\right)$, was statistically significantly increased, compared with $1^{\text {st }}$ day by $15.9 \%\left(0.36 \mu \mathrm{cat} \cdot \mathrm{kg}^{-1}\right)$. On the $7^{\text {th }}$ catalase activity decreased again, and relatively to the $3^{\text {rd }}$ day it was less by $9.5 \%\left(0.25 \mu \mathrm{cat} \cdot \mathrm{kg}^{-1}\right)$, and was lower relatively to the $1^{\text {st }}$ hour by $20.7 \%\left(0.62 \mu \mathrm{cat} \cdot \mathrm{kg}^{-1}\right)$. On the $14^{\text {th }}$ day the indicator remained statistically lower comparably to the $1^{\text {st }}$ hour by $17.7 \%\left(0.53 \mu \mathrm{cat} \cdot \mathrm{kg}^{-1}\right)$.

In the EG3 the expressed suppression of activity of catalase is fixed. On the $1^{\text {st }}$ day the indicator decreased compared to the $1^{\text {st }}$ hour by $23.7 \%\left(0.67 \mu \mathrm{cat} \cdot \mathrm{kg}^{-1}\right)$. On the $3^{\text {rd }}$ day the activity was lower, compared with the $1^{\text {st }}$ hour by $37.8 \%\left(\mu \mathrm{cat} \cdot \mathrm{kg}^{-1}\right)$, and compared with the $1^{\text {st }}$ day by $18.5 \%\left(\mu \mathrm{cat} \cdot \mathrm{kg}^{-1}\right)$. On the $7^{\text {th }}$ day the indicator decreased even more and was lower, compared to the $3^{\text {rd }}$ day, by $25 \%\left(0.44 \mu \mathrm{cat} \cdot \mathrm{kg}^{-1}\right)$, as well was less compared to the data of the $1^{\text {st }}$ hour by $53.4 \%\left(1.51 \mu \mathrm{cat} \cdot \mathrm{kg}^{-1}\right)$ and $1^{\text {st }}$ day - by $38.9 \%\left(0.84 \mu \mathrm{cat} \cdot \mathrm{kg}^{-1}\right)$, respectively. On the $14^{\text {th }}$ day a slight increase in catalase activity was fixes, compared to the data of the $7^{\text {th }}$ day by $22.7 \%\left(0.3 \mu \mathrm{cat} \cdot \mathrm{kg}^{-1}\right)$, but it still remained below compared to the level of $1^{\text {st }}$ hour and $1^{\text {st }}$ day by $42.8 \%\left(1.21 \mu \mathrm{cat} \cdot \mathrm{kg}^{-1}\right)$, by $25 \%\left(0.54 \mu \mathrm{cat} \cdot \mathrm{kg}^{-1}\right)$, respectively.

In EG4 the dynamics was as follows, but in all investigated period of time $\mathrm{p}$ was higher than 0.05 : on the $1^{\text {st }}$ day the catalase activity decreased compared to the $1^{\text {st }}$ hour by $3.8 \%\left(0.3 \mu \mathrm{cat} \cdot \mathrm{kg}^{-1}\right)$. On the $3^{\text {rd }}$ day it was decreased and lower compared to the $1^{\text {st }}$ hour - by $9.6 \%\left(0.39 \mu \mathrm{cat}^{\mathrm{kg}} \mathrm{kg}^{-1}\right)$. On the $7^{\text {th }}$ day, the indicator remained at the level of $3^{\text {rd }}$ day and was lower than the level of the 
$1^{\text {st }}$ hour by $10.3 \%\left(0.42 \mu \mathrm{cat} \cdot \mathrm{kg}^{-1}\right)$. On the $14^{\text {th }}$ day, the indicator returned to the level of the $1^{\text {st }}$ hour, exceeding the data of $7^{\text {th }}$ day and $11 \%\left(0.4 \mu \mathrm{cat} \cdot \mathrm{kg}^{-1}\right)$.

In EG5 on the $1^{\text {st }}$ day the indicator was lower than the level of the $1^{\text {st }}$ hour by $16.9 \%\left(0.65 \mu \mathrm{cat} \cdot \mathrm{kg}^{-1}\right)$, on the $3^{\text {rd }}$ day decreased by $10.7 \%\left(0.34 \mu \mathrm{cat} \cdot \mathrm{kg}^{-1}\right)$ compared to the $1^{\text {st }}$ day and remained reduced compared to the $1^{\text {st }}$ hour by $25.8 \%\left(0.99 \mu \mathrm{cat} \cdot \mathrm{kg}^{-1}\right)$. At $7^{\text {th }}$ day the decline in activity has been continuing when the rate was lower than the level of the $1^{\text {st }}$ hour and the $1^{\text {st }}$ day by $38.3 \%\left(1.47 \mu \mathrm{cat} \cdot \mathrm{kg}^{-1}\right)$ and $25.7 \%\left(0.82 \mu \mathrm{cat} \cdot \mathrm{kg}^{-1}\right)$. On the $14^{\text {th }}$ day, the activity began to recover slightly, compared with the data of the $7^{\text {th }}$ day, the indicator increased by $11.8 \%\left(0.28 \mu \mathrm{cat}^{\cdot} \mathrm{kg}^{-1}\right)$, but still remained lower than the data of the $1^{\text {st }}$ hour and $1^{\text {st }}$ day by $31 \%\left(1.19 \mu \mathrm{cat}^{\circ} \mathrm{kg}^{-1}\right)$, $16.9 \%\left(0.54 \mu \mathrm{cat} \cdot \mathrm{kg}^{-1}\right)$, respectively.

Analyzing the change in the studied indicator, the correlation between the severity of severe manifestations of inhibition of catalase activity was established, which testified to the most destructive effect of the combination of IRS with massive blood loss. Thus, after the $1^{\text {st }}$ hour the indicator in EG3 was lower than the data of EG1 by $43.1 \%\left(2.14 \mu \mathrm{cat} \cdot \mathrm{kg}^{-1}\right)$. Also, indicator in EG5 was lower than the data of EG1 by $22.7 \%\left(1.13 \mu \mathrm{cat} \cdot \mathrm{kg}^{-1}\right)$. On the $1^{\text {st }}$ day, the index in EG3 was lower than the data of EG1 by $58.5 \%\left(3.4 \mu \mathrm{cat} \cdot \mathrm{kg}^{-1}\right)$. Herewith, indicator of EG5 was lower comparably to data of EG1 by $38.7 \%\left(2.01 \mu \mathrm{cat} \cdot \mathrm{kg}^{-1}\right)$ and lower than data of EG4 by $15.2 \%\left(0.57 \mu \mathrm{cat} \cdot \mathrm{kg}^{-1}\right)$. On the $3^{\text {rd }}$ day the studied index was lower than in EG1 and EG2 in 6.2 times $\left(9.16 \mu \mathrm{cat}^{-1} \mathrm{~kg}^{-1}\right)$ and by $33.1 \%\left(0.87 \mu \mathrm{cat} \cdot \mathrm{kg}^{-1}\right)$; also it was lower in EG5 comparably to data of EG1 and EG4 in $3.8\left(8.07 \mu \mathrm{cat} \cdot \mathrm{kg}^{-1}\right)$ times and by $22.3 \%\left(0.82 \mu \mathrm{cat} \cdot \mathrm{kg}^{-1}\right)$, respectively. On the $7^{\text {th }}$ day catalase activity in EG3 was in 9.4 times $\left(11.4 \mu \mathrm{cat} \cdot \mathrm{kg}^{-1}\right)$ and by $44.5 \%$ times $\left(1,06 \mu \mathrm{cat} \cdot \mathrm{kg}^{-1}\right)$ lower than in EG1 and in EG2 data, respectively and in EG 5 the indicator was lower comparably to data of EG1 and EG4 in 5.2 times $\left(9.99 \mu \mathrm{cat} \cdot \mathrm{kg}^{-1}\right)$ and by $34.9 \%\left(1.27 \mu \mathrm{cat} \cdot \mathrm{kg}^{-1}\right)$, respectively. As for $14^{\text {th }}$ day the rate in EG3 was lower compared to EG1 and EG2 in 5.2 times $\left(6.76 \mu \mathrm{cat} \cdot \mathrm{kg}^{-1}\right)$ and by $34.4 \%\left(0.85 \mu \mathrm{cat} \cdot \mathrm{kg}^{-1}\right)$, and indicator in EG5 was lover comparably to data of EG1 and EG4 in 3.2 times $\left(5.73 \mu \mathrm{cat} \cdot \mathrm{kg}^{-1}\right)$ and by $34.4 \%\left(1.39 \mu \mathrm{cat} \cdot \mathrm{kg}^{-1}\right)$ respectively.

\section{Discussion}

In general, analyzing the dynamics of the activity catalase - the enzyme of the antioxidant system - we can identify the following pathogenetic factors that underlie similar changes. Previously we have found that each of these types of experimental interventions contributed to the growth of endogenous intoxication (EI) and stress impact for excretory renal function and the detoxifying role of the liver $[16,17]$. In this case, the more significant the level of EI, the more expressed suppression of antioxidant protection in almost all internal organs [18], and of course, in the liver.

Thus, it was possible to show that in the structure of the degrees of expression of the suppression of AOS the most critical was the combination of IR with heavy blood loss. Among the reasons that suppress the concentration of antioxidants are reactive oxygen species due to increased lipid peroxydation of cells membranes, oxidative stress [19]; in the structure of factors that can trigger previously mentioned processes are both hemic hypoxia [20] and the systemic inflammatory response syndrome $[21,22]$. In case of our experiments the realization of toxic substances that have accumulated as a result of 2-hour application of the tourniquet leads to the further release into the blood of products of damaged muscle tissue [23-25] on the background of endothelial dysfunction of the microcirculatory tract [26].

Researchers also point to the special insidiousness of the development of the syndrome of multiorgan damage and the subsequent mutual reinforcement of existing manifestations. The results of the studies highlighted the role of ischemic reperfusion of the limb on the systemic manifestations of mechanical trauma and volumetric blood loss.

Study limitations. A limitation of our study is the investigation of effect of 2-hour imposition of tourniquet into the tie and its effect to antioxidant activity of liver, while the reactive forms of oxygen were neglected. Thus, obtained information was in accordance with previously elucidated data of lipid peroxidation activity in this organ.

Prospects for further research. Further studies of the problem of postischemic complications, mainly associated with hypoxic disorders on the background of heavy blood loss, required further 
investigation of changes in other internal organs and describing of systemic expressions of this pathology. At the same time, the establishment of critical periods when oxidative stress is in its peak and the greatest inhibition of AOS appears can help in avoiding of complications after reinfusion therapy. The following data will help in optimisation of treatment regimen, in particular actions in the first hours after bleeding, when additionally drug administration, antioxidants, could be recommended.

\section{Conclusions}

In this experiment, founded risk factors of combination of ischemia-reperfusion with heavy blood loss emphasized the importance and particular attention on such widespread method of bleeding treatment, as the imposition of a tourniquet, as in our experiment it triggered risk factors of ischemia-reperfusion. It was shown catalase activity depression respectively to the periods of increasing of lipid peroxydation. There was peculiarity, that on the base of isolated IRS catalase activity was increased in 2.5 times comparably to control group, whereas the hardest depression of it was found on the background of IRS, combined with blood loss - catalase activity was lower, compare to $\mathrm{KG}$ - in 2.5 times. The importance of understanding the suppression of hepatocytes' antioxidants is great, as it might help in prevention the development of liver failure or hepatorenal syndrome on the background of limb ischemia-reperfusion.

\section{Conflict of interests}

The authors declare that they have no conflicts of interest.

\section{References}

[1] Coling, D., Chen, S., Chi, L.-H., Jamesdaniel, S., Henderson, D. (2009). Age-related changes in antioxidant enzymes related to hydrogen peroxide metabolism in rat inner ear. Neuroscience Letters, 464 (1), 22-25. doi: http://doi.org/10.1016/ j.neulet.2009.08.015

[2] Davies, K. (2001). An Overview of Oxidative Stress. IUBMB Life, 50 (4), 241-244. doi: http://doi.org/10.1080/713803723

[3] Bissinger, R., Bhuyan, A. A. M., Qadri, S. M., Lang, F. (2018). Oxidative stress, eryptosis and anemia: a pivotal mechanistic nexus in systemic diseases. The FEBS Journal, 286 (5), 826-854. doi: http://doi.org/10.1111/febs.14606

[4] Gulek, B.; Trzcinska, M. (Ed.) (2011). Ischemia Reperfusion Injury in Kidney Transplantation. Kidney Transplantation - New Perspectives, 214-222. doi: http://doi.org/10.5772/18289

[5] Glorieux, C., Calderon, P. B. (2017). Catalase, a remarkable enzyme: targeting the oldest antioxidant enzyme to find a new cancer treatment approach. Biological Chemistry, 398 (10), 1095-1108. doi: http://doi.org/10.1515/hsz-2017-0131

[6] Nadeem, M. S., Khan, J. A., Murtaza, B. N., Muhammad, K., Rauf, A. (2015). Purification and Properties of Liver Catalase from Water Buffalo (Bubalus bubalis). South Asian Journal of Life Sciences, 3 (2), 51-55. doi: http://doi.org/10.14737/ journal.sajls/2015/3.2.51.55

[7] Erturk, E. (2014). Ischemia-Reperfusion Injury and Volatile Anesthetics. BioMed Research International, 2014, 1-7. doi: http:// doi.org/10.1155/2014/526301

[8] Bordakov, V. N., Alekseev, S. A., Chumanevich, O. A., Patsay, D. I., Bordakov, P. V. (2013). Crash-syndrome. Military medicine, 1, 26-32. Available at: http://rep.bsmu.by/handle/BSMU/2213

[9] Fernández, A. R., Sánchez-Tarjuelo, R., Cravedi, P., Ochando, J., López-Hoyos, M. (2020). Review: Ischemia Reperfusion Injury - A Translational Perspective in Organ Transplantation. International Journal of Molecular Sciences, 21 (22), 8549. doi: http://doi.org/10.3390/ijms21228549

[10] Teli, A., Ghatnatti, R. (2020). Association between blood transfusion and serum creatinine as a major risk factor in patients undergoing cardiac surgeries: An observational study. National Journal of Physiology, Pharmacy and Pharmacology, 10 (1), 59-63. doi: http://doi.org/10.5455/njppp.2020.10.1135913112019

[11] Tsymbaliuk, H. Y. (2018). Daily urine renal state under ischemic-reperfusion syndrome of limbs, abdominal injury with hypovolemic shock and their combination in the early period of traumatic disease. Achievements of clinical and experimental medicine, 3, 163-169.

[12] Wall, P. L., Duevel, D. C., Hassan, M. B., Welander, J. D., Sahr, S. M., Buising, C. M. (2013). Tourniquets and Occlusion: The Pressure of Design. Military Medicine, 178 (5), 578-587. doi: http://doi.org/10.7205/milmed-d-12-00490

[13] Pro zatverdzhennia Poriadku provedennia klinichnykh vyprobuvan likarskykh zasobiv ta ekspertyzy materialiv klinichnykh vyprobuvan i Typovoho polozhennia pro komisii z pytan etyky (2009). Law of the Ministry of Health of Ukraine No. 690. 23.09.2009. Available at: https://zakon.rada.gov.ua/laws/show/z1010-09\#Text 
[14] Korolyuk, V. A., Ivanova, L. I., Mayorova, I. G., Tokarev, V. E. (1988). Method for determining catalase activity. Laboratory work, 1, 16-19.

[15] Televiak, A. T. (2018). The dynamic of indicators of lipid peroxidation and antioxidant protection in muscle tissue of the hind limbs of the rats in development of the ischemic-reperfusion syndrome (experimental study). Achievements of clinical and experimental medicine, 3, 132-139. doi: http://doi.org/10.11603/1811-2471.2018.v0.i3.9318

[16] Volotovska, N. V., Hudyma, A. A. (2020). Features of hepatorenal reaction on the background of experimental ischemic-reperfusion syndrome. Bulletin of Problems Biology and Medicine, 2 (156), 86-91. doi: http://doi.org/10.29254/ 2077-4214-2020-2-156-86-91

[17] Volotovska, N. V., Hudyma, A. A. (2020). Significance of endogenous intoxication markers in the prognosis assessment of ischemic reperfusion limb syndrome. Bulletin of medical and biological research, 3 (5), 24-31. doi: http://doi.org/10.11603/ bmbr.2706-6290.2020.3.11357

[18] Bensard, D. D., Brown, J. M., Anderson, B. O., Banerjee, A., Shanley, P. F., Grosso, M. A. et. al. (1990). Induction of endogenous tissue antioxidant enzyme activity attenuates myocardial reperfusion injury. Journal of Surgical Research, 49 (2), 126-131. doi: http://doi.org/10.1016/0022-4804(90)90250-6

[19] Vertuani, S., Angusti, A., Manfredini, S. (2004). The Antioxidants and Pro-Antioxidants Network: An Overview. Current Pharmaceutical Design, 10 (14), 1677-1694. doi: http://doi.org/10.2174/1381612043384655

[20] Gutierrez, G., Reines, H. D., Wulf-Gutierrez, M. (2004). Clinical review: Hemorrhagic shock. Critical care, 8 (5), $373-381$. doi: http://doi.org/10.1186/cc2851

[21] Churpek, M. M., Zadravecz, F. J., Winslow, C., Howell, M. D., Edelson, D. P. (2015). Incidence and Prognostic Value of the Systemic Inflammatory Response Syndrome and Organ Dysfunctions in Ward Patients. American Journal of Respiratory and Critical Care Medicine, 192 (8), 958-964. doi: http://doi.org/10.1164/rccm.201502-0275oc

[22] NeSmith, E. G., Weinrich, S. P., Andrews, J. O., Medeiros, R. S., Hawkins, M. L., Weinrich, M. C. (2011). Demographic Differences in Systemic Inflammatory Response Syndrome Score After Trauma. American Journal of Critical Care, 21 (1), 35-41. doi: http://doi.org/10.4037/ajcc2012852

[23] Knafl, E. G., Hughes, J. A., Dimeski, G., Eley, R. (2018). Rhabdomyolysis: Patterns, Circumstances, and Outcomes of Patients Presenting to the Emergency Department. Ochsner Journal, 18 (3), 215-221. doi: http://doi.org/10.31486/toj.17.0112

[24] Park, J.-S., Seo, M.-S., Gil, H.-W., Yang, J.-O., Lee, E.-Y., Hong, S.-Y. (2013). Incidence, Etiology, and Outcomes of Rhabdomyolysis in a Single Tertiary Referral Center. Journal of Korean Medical Science, 28 (8), 1194-1199. doi: http://doi.org/ 10.3346/jkms.2013.28.8.1194

[25] Candela, N., Silva, S., Georges, B., Cartery, C., Robert, T. et. al. (2020). Short- and long-term renal outcomes following severe rhabdomyolysis: a French multicenter retrospective study of 387 patients. Annals of Intensive Care, 10 (1). doi: http:// doi.org/10.1186/s13613-020-0645-1

[26] Pianta, T. J., Succar, L., Davidson, T., Buckley, N. A., Endre, Z. H. (2017). Monitoring treatment of acute kidney injury with damage biomarkers. Toxicology Letters, 268, 63-70. doi: http://doi.org/10.1016/j.toxlet.2017.01.001

How to cite: Volotovska, N. (2021). Catalase activity as signal of antioxydant system affection under influence of limb ischemiareperfusion. EUREKA: Health Sciences, 2, 24-30. doi: http://doi.org/10.21303/2504-5679.2021.001648 